\title{
Analysis of Dendritic-Cell-Induced Primary T-Cell Responses Between HLA Genotypically Identical Individuals
}

\author{
E. G. van Lochem, A. Bakker, E. C. M. Hoefsmit, \\ G. C. de Gast, and E. Goulmy
}

\begin{abstract}
DCs are known for their superior antigenprocessing and antigen-presenting capacities They are capable of processing intact protein either endocytosed exogenous proteins or newly synthesized endogenous viral and bacterial proteins They are potent inducers of primary $\mathrm{T}$-cell immune responses such as in allogenerc MLRs It is also known that DCs can provide a strong stimulus for autologous $T$-cell proliferation So far no information exists on the capacity of DCs to induce primary $\mathrm{mH}$ antigen-specific $\mathrm{T}$-cell responses Therefore, we investigated whether human DCs, isolated from peripheral blood, were able to generate specific $T$-cell responses between MLR-negative HLA genotypically identical in-
\end{abstract}

dividuals in vitro To this end, unfractionated cells, monocytes, and B cells were assayed in parallel with DCs to compare their capacity to activate unprimed $T$ cells in a primary MLR DCs indeed induced significant proliferation between HLA genotypically identical siblings, whereas the other APCs were unable to evoke any T-cell response at all As expected, besides these allogeneic $T$-cell responses, autologous $T$-cell responses were inttated by the DCs as well Nonetheless, despite further detailed analyses of the responding $T$ cells, netther proliferative nor cytotoxic $\mathrm{mH}$ antigen-specific reactivities could yet be detected using the stimulation protocols described herein Human Immunology 44, 181-188 (1995)

\begin{tabular}{|c|c|}
\hline \multicolumn{2}{|c|}{ ABBREVIATIONS } \\
\hline \multicolumn{2}{|c|}{ APC anrigen-presenting cell } \\
\hline BMT & bone marrow transplantacion \\
\hline $\mathrm{DC}$ & dendritıc cell \\
\hline EBV-LCL & $\begin{array}{l}\text { Epstein-Barr virus-transformed B-cell } \\
\text { line }\end{array}$ \\
\hline ER & erythrocyce rosette \\
\hline GAM & goat-ant1-mouse \\
\hline GvHD & graft-versus-host disease \\
\hline
\end{tabular}

\section{INTRODUCTION}

Despite advances in bone marrow transplantation (BMT) conditioning, better graft-versus-host disease (GvHD) prophylaxis, and HLA matching, the occurrence of GrHD is still a major drawback in allogenerc BMT. In

From the Department of Immunabematology and Blood Bank ( $E$ G $v L$, $A B, E G)$, Letden Unversity Hosputal, Leiden, the Department of Cell Brology (E C M H ), Division Electron Mrcroscopy, Medrcal Faculity, Free Untversity, Amsterdam, and the Department of Hematology ( $G C d G$ ), Unwerstty Hosptial, Utrecht, The Netberlands

Address reprint requests to $\mathrm{Dr} E G$ van Locbem, Department of Immunobematology and Blood Bank, Leiden Unversity Hospital Butlding 1 E3-Q, POB 9600, 2300 RC Letden, The Netherlands

Recetved (U) August 1, 1994, accepted November 4, 1994

$\begin{array}{ll}\text { mAb } & \text { monoclonal antibody } \\ \text { mH } & \text { minor histocompatibility } \\ \text { MHC } & \text { major histocompatibility complex } \\ \text { MLDCR } & \text { mixed leukocyte DC reaction } \\ \text { MLR } & \text { mixed leukocyte reaction } \\ \text { NK } & \text { natural killer } \\ \text { PBMC } & \text { peripheral blood mononuclear cell } \\ \text { PLT } & \text { primed lymphocyte test }\end{array}$

HLA genotypically identical combinations, differences for minor histocompatibility $(\mathrm{mH})$ antigens between $\mathrm{BM}$ donor and recipient can play a role in the development of GvHD [1] These $\mathrm{mH}$ antigen differences cannot be identified in a primary mixed leukocyte reaction (MLR) In vivo priming prior to in vitro sensitization is generally required to elicit $T$-cell responses in vitro against such disparities In this study, we focused on the use of a more adequate antıgen-presentıng cell (APC) as stımulator cell to attempt to induce primary $\mathrm{mH}$ antıgen-specific $\mathrm{T}$-cell responses in vitro

Previous studies have identified human dendritic cells (DCs) as a small fraction $(<1 \%)$ of peripheral blood 
mononuclear cells (PBMCs) $[2,3]$. Human blood DCs share the distinctive features of their counterparts in other species such as cell shape and abundant expression of major histocompatibility complex (MHC) class I and II products [4-8], although they cannot yet be identified by specific cell markers in the same manner as, for example, 33D1 and murine DCs [9]. DCs are the most potent inducers of both alloreactive and autoreactive $T$ cells $[3,10]$; furthermore, they are very efficient in priming resting $T$ cells in vitro. Moreover, it has been shown that DCs pulsed with protein antigen are capable of priming antigen-specific MHC-restricted $\mathrm{T}$ cells both in vivo and in vitro [11-14].

Based on this knowledge, we performed a series of mixed lymphocyte DC reactions (MLDCRs) using DC as stimulators, to ascertain whether $\mathrm{mH}$ antigen differences between healthy HLA genotypically identical, MLRnegative sibling pairs could be demonstrated. The responding $T$ cells, both cytotoxic and proliferative, were analyzed in detail for their antigen-specific reactivities.

\section{MATERIALS AND METHODS}

Human subjects. Buffy coats from 0.51 of blood were obtained from 13 healthy HLA genotypically identical sibling pairs and two twin pairs. HLA typing was performed by serology for HLA-A, -B, -C, -DR, and -DQ and by oligonucleotide typing for HLA-DP. All of the pairs used in this study were fully HLA identical and nonproliferative in a standard MLR.

Isolation of DC: cell separation. Enrichment of DC was performed according to the method described by Freudenthal and Steinman [9] with minor modifications. In short, PBMCs were separated into T-cell-enriched (erythrocyte rosette-positive $\left[\mathrm{ER}^{+}\right]$) and T-cell-depleted (ER ${ }^{-}$) fractions by rosetting with AET-treated sheep red blood cells. $\mathrm{T}$ cells were recovered from $\mathrm{ER}^{+}$fractions by lysing the erythrocytes in $\mathrm{NH}_{4} \mathrm{Cl}$, yielding $>95 \%$ $\mathrm{CD}^{+} \mathrm{T}$ cells. The $\mathrm{T}$-cell-depleted fraction was cultured for 36 hours in tissue culture dishes. By reculturing the dislodged cells twice, monocytes selectively attached to the plastic culture dishes. The adherent monocytes could be collected by firm scraping. Nonadherent cells were layered onto $14.5 \%$ metrizamide to separate $B$ and natural killer (NK) cells from the DCs. Residual monocytes or B cells in the low-density fraction could be depleted by using magnetic beads (Dynal, Norway) which had a primary coat of goat-anti-mouse (GAM) IgG and a secondary coar of anti-CD14 or anti-CD19 mouse IgG.

The monocyte, B/NK cell, and DC fractions derived from the cell separation, as just described, were analyzed on a FACScan (Becton-Dickinson) for purity and MHC class II expression by staining with mouse monoclonal antibody ( $\mathrm{mAb}$ ) either directly labeled or indirectly labeled with fluorescein-conjugated GAM antibodies (Becton-Dickinson). Expression of high levels of MHC II (DR, DP, and DQ) molecules, in addition to the absence of lineage-specific markers, is a distinctive feature of DCs [6-9]. $\mathrm{mAb}$ directed at the latter molecules were therefore used to identify DCs and to distinguish them from residual monocytes and $\mathrm{B}$ cells in the purified fraction. To confirm the FACS analyses, in some cases cytospin preparations of the DC-enriched fractions were stained for acid phosphatase and MHC class II, and/or electron microscopy of these fractions was performed.

T-cell proliferation assay: $M L D C R$. From 13 HLA genotypically identical MLR-negative sibling pairs and two twin pairs, primary proliferation assays were performed. Each cell type, i.e., monocytes, B cell, NK cells, and DCs, isolated as just described, was tested simultaneously in the same experiment for its stimulatory capacity. As responder cells, both $\mathrm{T}$ cells and unseparated PBMCs were assayed. All MLDCRs were carried out as follows. Threefold serial dilutions $\left(1.5 \times 10^{4}\right.$ to 50 cells/well) of irradiated ( $3000 \mathrm{rad})$ stimulator cells were added in quintuplicate to $5 \times 10^{4}$ responder cells in 96-well round-bottom plates. After 5 days of cuiture, 1 $\mu \mathrm{Ci} /$ well $\left[{ }^{3} \mathrm{H}\right]$ thymidine was added to the MLDCR for the last 16-18 hours.

Generation of T-cell lines. DC-induced T-cell responses of eight of the 13 HLA genotypically identical MLRnegative sibling pairs were further analyzed. T-cell responses were initiated either with a CD4-depleted T-cell population or with purified nondepleted $T$ cells, and stimulated with DCs. T-cell lines were established either by weekly stimulation with PBMCs and Epstein-Barr virus-transformed B-cell lines (EBV-LCLs) of the specific stimulator in the presence of $1 \%$ leuco-A and $20 \mathrm{U} / \mathrm{ml}$ rIL-2 (designated as "standard protocol"), or by adding a single dose of rIL-7 $(60 \mathrm{ng} / \mathrm{ml}) 36$ hours after the initiation of the culture (designated as "rIL-7 protocol"). In the latter protocol, T-cell lines could be cultured and expanded for 3 weeks without the addition of other cytokines or specific stimulator cells. All T-cell lines were analyzed weekly on a FACScan for their $\mathrm{CD} 3, \mathrm{CD} 4$, and CD8 expression.

Primed lymphocyte test ( $\left.P L T^{\prime}\right)$. To assay the secondary proliferarive response, the T-cell lines were repeatedly tested in PLT. Responder T cells, $10^{4}$, were added to either $10^{5}$ PBMCs (3000 rad irradiated) or $0.25 \times 10^{5}$ EBV-LCL (8000 rad irradiated) in 96-well flat-bottom plates. These were performed in triplicate. Proliferation was expressed in stimulation indices (SI): 


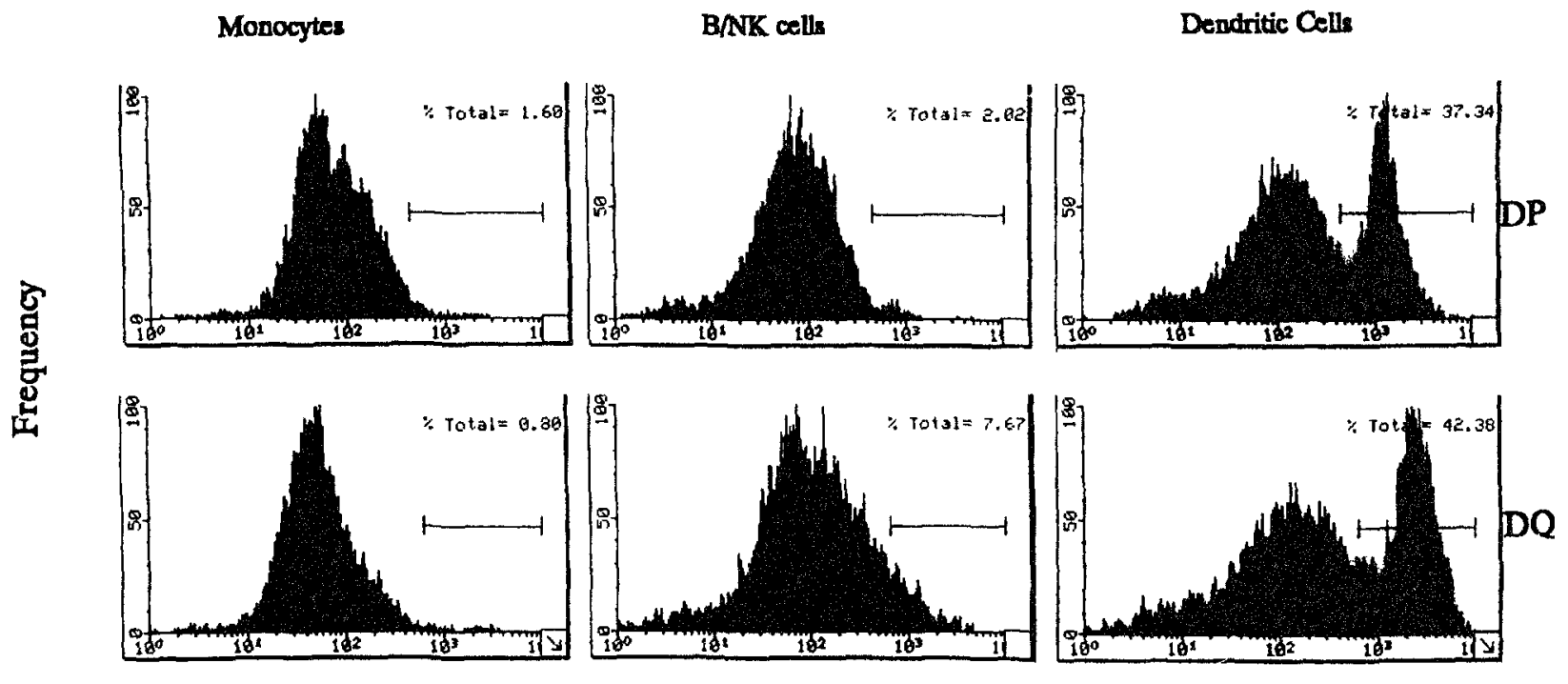

Fluorescence Intensity

FIGURE 1 All enriched fractions were analyzed on a FACScan for purity. To estimate the percentage of DCs in the DC-enriched fraction, the high expression of MHC class II molecules was used as a distinctive feature, besides the absence of $\mathrm{CD} 3, \mathrm{CD} 14, \mathrm{CD} 19, \mathrm{CD} 16$, and CD56. A high expression of HLA-DP and HLA-DQ was shown on a population of cells in the DC-enriched fraction but was absent on the other isolated fractions; i.e., monocytes (>95\% CD14 ${ }^{+}$) and $\mathrm{B} / \mathrm{NK}$ cells (consists of $60 \%$ of B cells and $20 \%$ of NK cells).

$$
\mathrm{SI}=\frac{\text { cpm experimental combination }}{\begin{array}{c}
\text { cpm responders alone }+ \\
\text { cpm stimulators alone }
\end{array}}
$$

Cytotoxicicity assay. Cytotoxicity of the T-cell lines was assayed repeatedly in a standard chromium-release assay [15] at different effector-target cell ratios. Phytohemagglutinin-stimulated PBMCs (i.e., PHA blasts) or EBVLCLs were used as target cells and added in duplicate to the effector $\mathrm{T}$ cells. Percentages of specific ${ }^{{ }^{1} 1} \mathrm{Cr}$ release were calculated as follows:

$$
\% \text { lysis }=\frac{\begin{array}{c}
\text { experimental release }- \\
\text { spontaneous release }
\end{array}}{\begin{array}{l}
\text { maximal release }- \\
\text { spontaneous release }
\end{array}} \times 100 \%
$$

Cell culture medium. RPMI 1640 (Gibco) was supplemented with antibiotics $(100 \mathrm{IU} / \mathrm{ml}$ penicillin and 100 $\mu \mathrm{g} / \mathrm{ml}$ streptomycin) and $\mathrm{L}-\mathrm{glutamine}(3 \mathrm{mM})$ and $10 \%$ human serum.

\section{RESULTS}

DC isolation. DCs were enriched from buffy coats of healthy blood donors. As analyzed on a FACScan, all DC preparations contained $>50 \%$ DCs. Figure 1 shows DC expressing high levels of MHC class II products. These high MHC class II expressing cells were found to be negative for the markers CD3, CD 14, CD19, CD16, and CD56 in double staining tests (data not shown). The FACScan analyses were confirmed by electronmicroscopy (Fig. 2A) and by cytospin preparations, stained for MHC II and acid phosphatase (as shown in Fig. 2B). In both tests the majority of cells in the enriched fraction could be identified as DCs. Cells contaminating the DC fractions were mostly NK cells and less than $10 \%$ residual monocytes.

DCs induce primary MLRs between HLA-identical siblings. The capacity of DCs to induce primary T-cell responses was analyzed in 13 HLA genotypically identical sibling pairs and two twin pairs. All combinations were negative in a standard MLR. The superior stimulatory capacity of DCs was clearly shown by simultaneously comparing monocytes and $B$ cells as stimulator cells in a primary proliferation assay (Fig. 3). Even at the highest concentration of stimulator cells per well, monocytes, B cells, or unfractionated PBLs were not able to yield a response comparable to DCs. Of the thirteen HLA genotypically identical sibling pairs, 10 displayed a positive MLDCR. In three of the $13 \mathrm{HLA}$-identical sibling pairs the MLDCR was negative (data not shown). The primary $T$-cell responses of five of the 10 MLDCRpositive sibling pairs and of one of the two twin pairs (pair no. 9405) are depicted in Fig. 4. Although in the five sibling combinations shown in Fig. 4 a significant MLDCR is demonstrated, it is clear that a variability in responsiveness both within and between the HLA identical pairs is also observed. None of the twin pairs demonstrated a proliferative $T$-cell response. The results from 


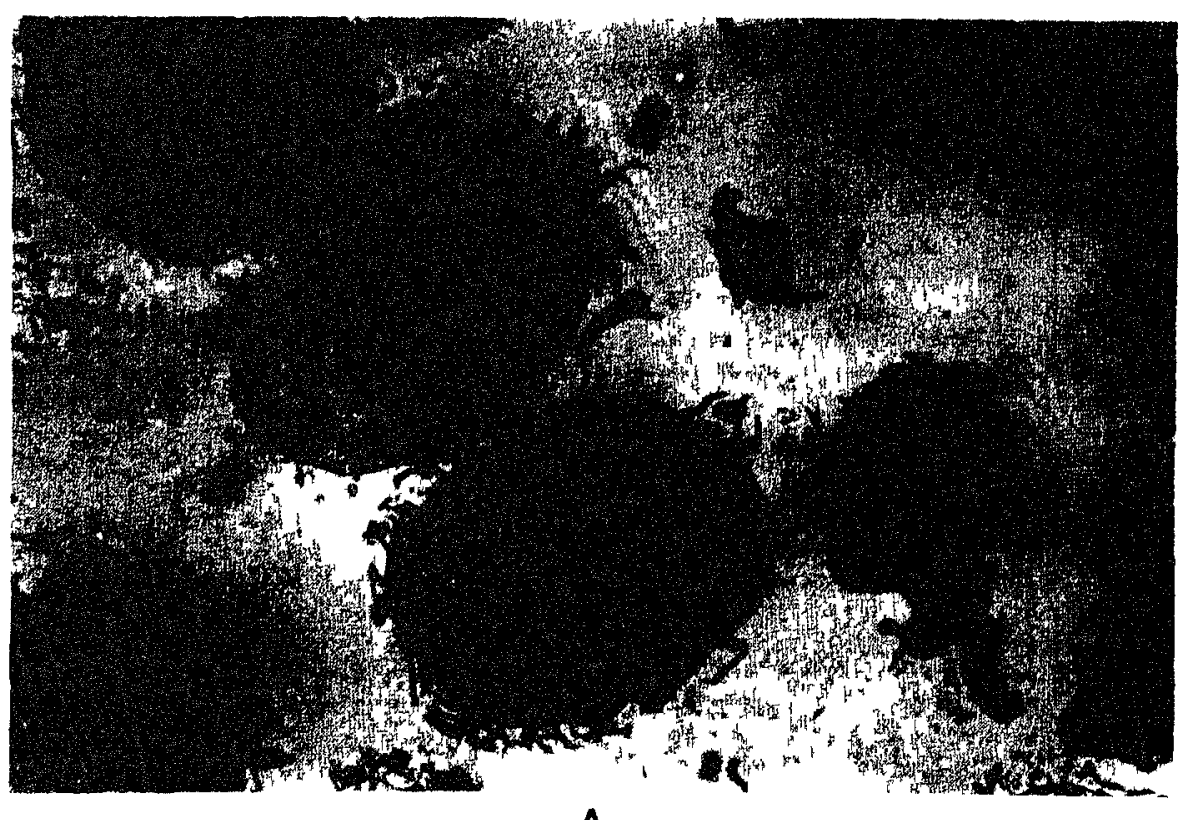

A

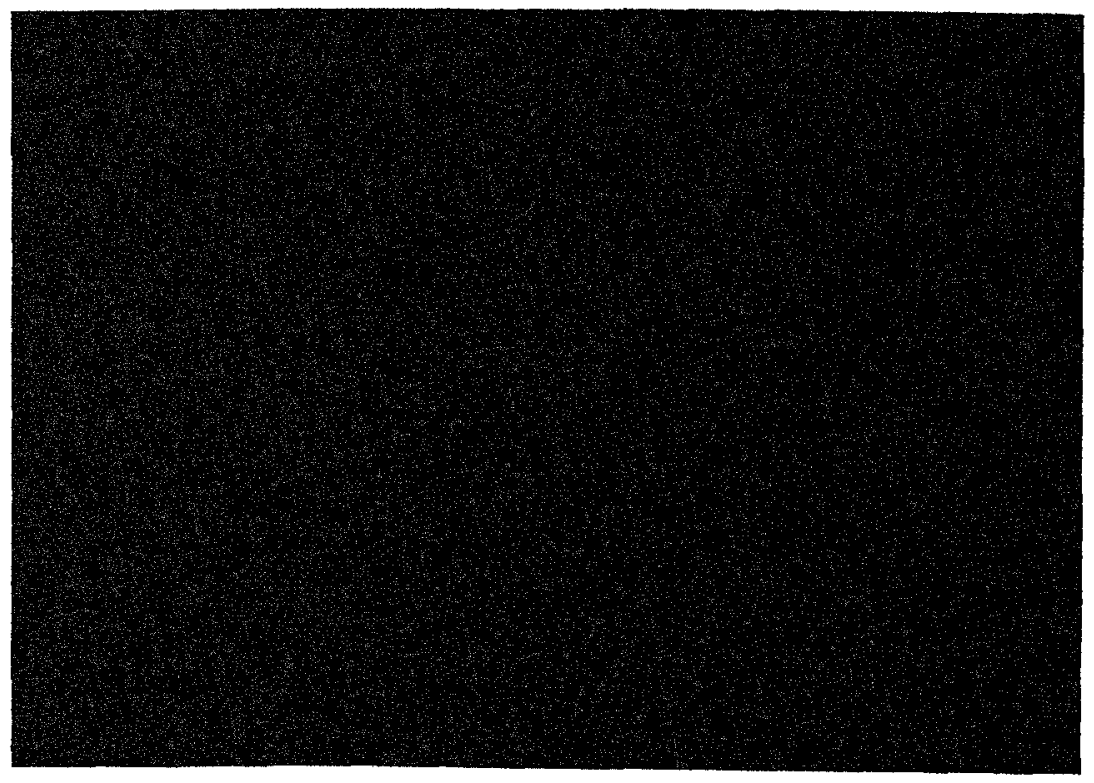

B

FIGURE 2 Electron microscopic analysis of the DCenriched fraction confirmed the characteristic morphology of DCs (A). Cytospin preparations provided an extra help in the identification of DCs DCs show a distinctive morphology and have a cluster of acid-phosphatase-rich endosomes near the nucleus (B)

a representarive twin pair (pair no 9405) are shown in Fig 4. Both positive and negative responses were found to be reproducible

In some combinations the DC induced high autologous responses This property is inherent to the potent APC function of the DC and was noted earlier by other investigators [3] Nonetheless, it interfered with the interpretation of the results of the MLDCR (Fig 4 pair no $9557 \mathrm{~B} \times \mathrm{B}$ and pair no $9379 \mathrm{~A} \times \mathrm{A}$ ) In an attempt to avord these autologous responses, the DC isolation and the MLDCR test were performed in aurologous plasma instead of alloserum, however, this did not eliminate the autologous responses (data not shown).

Analysis of $D C$-induced $T$-cell responses To analyze the specificity of the DC-induced T-cell responses, T-cell lines were generated from eight HLA genotypically identical sibling combinations in which the MLDCR was 


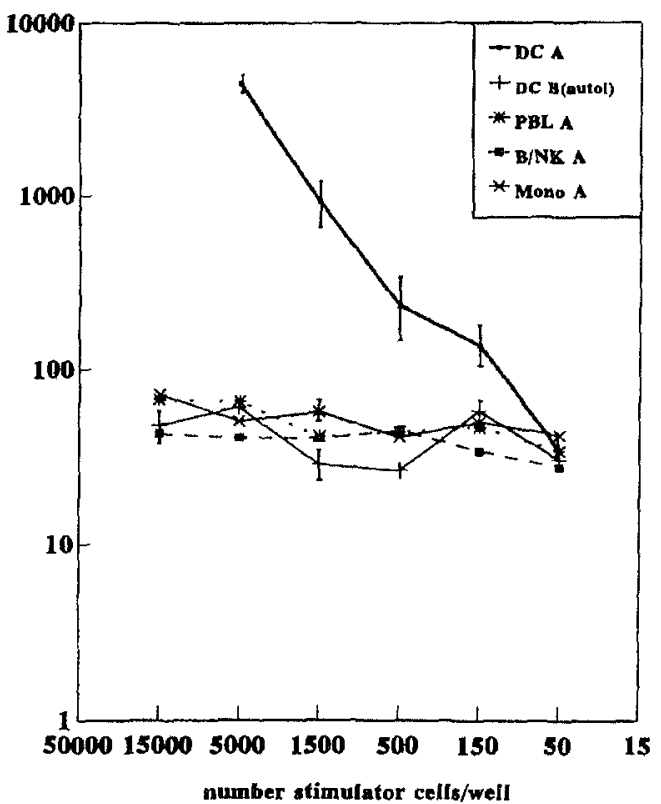

FIGURE 3 The stimulatory capacities of different APCs (DCs, monocytes, B/NK cells, and unseparated PBMCs) were compared in a primary proliferation assay. Concentrations of $1.5 \times 10^{4}$ to 50 stimulator cells/well were used to stimulate $5 \times 10^{4}$ responder $T$ cells. The response of individual $A$ against the different APCs from individual $B$ from pair no. 9384, which is representative for the other sibling combinations, is depicted. Symbols give mean \pm standard error of the mean (SEM; $n=5$ ). The error bars were omitted when they fell within the symbol.

found to be positive. T-cell responses were initiated with either a CD4-depleted T-cell population or nondepleted purified $T$ cells and stimulated with DCs. Responding $T$ cells were further expanded using either the standard protocol or the rIL-7 protocol (see Material and Methods). The $\mathrm{T}$-cell lines induced by DC were functionally analyzed for cytotoxicity in a CML assay and for proliferative activity in a PLT assay at least twice. CD4/CD8 phenotype of the T-cell lines (all $\mathrm{CD} 3$ positive) was analyzed on a FACScan. The results are summarized in Table 1. Autologously induced $\mathrm{T}$-cell lines (i.e., $\mathrm{A} \times \mathrm{A}$ or $\mathrm{B} \times \mathrm{B}$ ) are not depicted in Table 1 , as most of these lines were difficult to expand and did not exhibit any functional activity. Analysis of the phenotype of the DC-induced T-cell lines revealed an overgrowth of the CD4 phenotype in all cases where the responder cell population was not depieted for CD4. This overgrowth of the CD4 phenotypic $T$ cells was more pronounced when the standard protrcol was used for expansion of the $T$-cell lines. T-cell lines of mainly CD8 phenotype could therefore only be established when the responding $T$-cell population was depleted for CD4 prior to the initiation of the response with DCs. The CD8-positive $T$ cells were most efficiently expanded by using the fIL-7 protocol.

As outlined earlier, all $\mathrm{T}$-cell lines were assayed for their functional activity at least twice. In Table 1, proliferative and cytotoxic activity of the T-cell lines between 2 and 3 weeks of culture are depicted. Functional analyses revealed no cytotoxic activity of the DC-induced $T$-cell lines generated with nondepleted purified $T$ cells, independent of the culture protocol used for expansion. Cytotoxic activity was observed in the T-cell lines induced with CD4-depleted $T$ cells; these latter activities, however, were equally strong both to the autologous and specific target cells. DC-induced proliferative activity could be observed in both the CD4-depleted and nondepleted $\mathrm{T}$-cell lines. Similar to the cytotoxic responses, the proliferative activities were directed against autologous and specific stimulator cells. The $T$-cell line from pair no. 9607-2 displayed, besides a weak cytotoxic response, a strong proliferative activity.

It is clear from these results that both the proliferative and the cytotoxic $T$-cell lines react to the same extent with autologous cells and cells of the HLA-identical sibling to which the response was induced. Because the functional activity of the $T$-cell lines reflects a summation of T-cell clones with various specificities, we performed analysis at the clonal level aimed at separating potential $\mathrm{mH}$ antigen-specific $\mathrm{T}$-cell clones from autoreactive $T$-cell clones. Analysis of the clones obtained from $0.3 \mathrm{cell} / \mathrm{well}(N=63)$ and from $1 \mathrm{cell} / \mathrm{well}(N=73)$ from a T-cell line (pair no. 9384-2 B $\times$ A) showed that these clones exhibited the same functional activity as the $T$-cell line, i.e., reactive against both the autologous and specific stimulator cells (data not shown).

\section{DISCUSSION}

$\mathrm{mH}$ antigen differences between HLA-identical siblings can form transplantation barriers in allogeneic BMT [1]. In previous studies we observed a significant correlation between post-BMT anti-host proliferative $\mathrm{mH}$ antigenspecific $T$-cell responses and acute GvHD [16]. T-cell responses evoked by $\mathrm{mH}$ antigen disparities between bone marrow donor and recipient are generally not observed in a primary MLR. However, it was recently shown that putative $\mathrm{mH}$-specific and/or as yet unidentified major $\mathrm{H}$ antigenic $\mathrm{T}$-cell responses can be generated in vitro without prior in vivo priming by applying a limiting dilution system [17-19]. Schwarer et al. [18] and Theobald et al. [19] used IL-2 production by responder cells as an indication of $T$-cell activation.

By using an alternative approach, we investigated the capacity of DCs to induce primary proliferative and $c y$ totoxic $T$-cell responses in HLA genotypically identical, MLR-negative sibling combinations. We found that DCs were indeed capable of inducing $T$-cell proliferation in these combinations. The superior stimulatory capacity of DCs was further apparent when simultaneously comparing unseparated PBMCs, monocytes, and $B$ cells as 

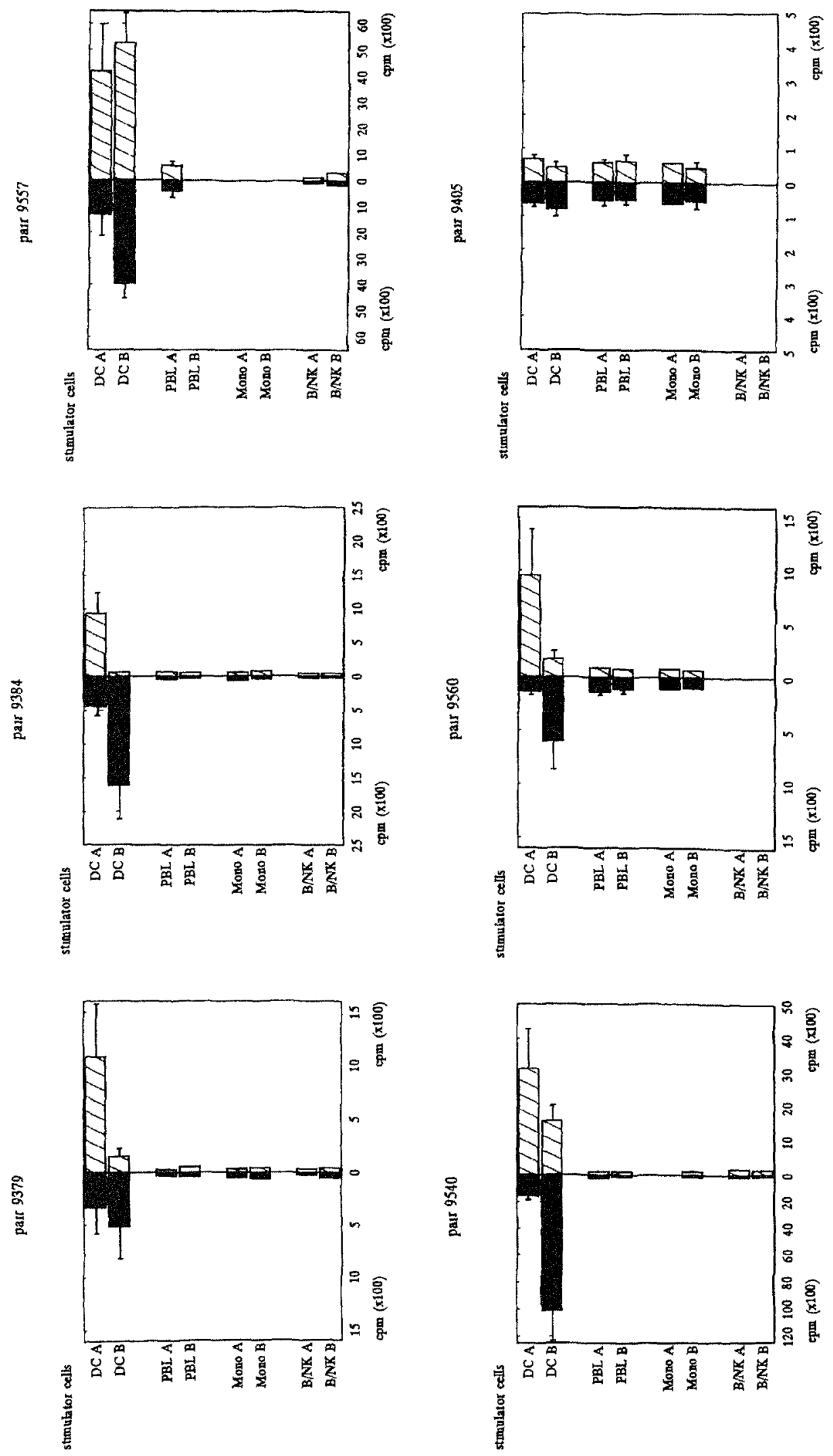

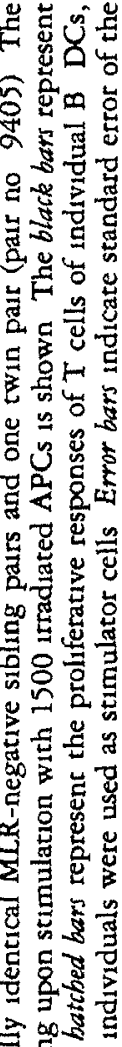

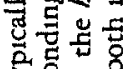

运安

总焉竞

$4 \overline{8}$

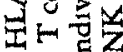

웅용

岁×禺

出岇造

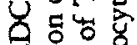

究导

逭客的

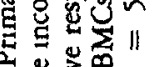

兘是 =

*

号㤩员员品

武密焉总 
TABLE 1 Analyses of DC-induced $T$ cell lines from HLA-1dentical-sibling combinations

\begin{tabular}{|c|c|c|c|c|c|c|c|c|c|}
\hline \multirow[b]{2}{*}{ Paur no } & & \multirow{2}{*}{$\begin{array}{c}\mathrm{CD}^{\prime} \\
\text { depleted }\end{array}$} & \multirow[b]{2}{*}{ Protocol ${ }^{r}$} & \multicolumn{2}{|c|}{$\mathrm{CML}^{d}$} & \multicolumn{2}{|c|}{ PLT } & \multicolumn{2}{|c|}{ Phenotype } \\
\hline & & & & Auto & Spec & Auto & Spec & $\% \mathrm{CD} 4$ & $\% \mathrm{CDB}$ \\
\hline \multirow[t]{2}{*}{9606} & $A \times B$ & No & Standard & - & - & - & - & 65 & 30 \\
\hline & $B \times A$ & No & Standard & - & - & + & + & 76 & 20 \\
\hline \multirow[t]{2}{*}{9605} & $A \times B$ & No & Standard & - & - & + & + & 58 & 36 \\
\hline & $B \times A$ & No & Standard & - & - & + & + & 81 & 17 \\
\hline \multirow[t]{2}{*}{$9607-1$} & $A \times B$ & No & Standard & - & - & ++ & ++ & 89 & 8 \\
\hline & $\mathrm{B} \times \mathrm{A}$ & No & Standard & - & - & ++ & ++ & 93 & 4 \\
\hline \multirow[t]{2}{*}{ 9384-I } & $A \times B$ & No & r-IL7 & $\mathrm{NG}^{8}$ & $N G$ & NG & $N G$ & & \\
\hline & $B \times A$ & No & r-IL7 & - & - & +++ & $++t$ & 63 & 31 \\
\hline \multirow[t]{2}{*}{9560} & $A \times B$ & No & $\mathrm{F}-\mathrm{IL7} 7$ & - & - & - & - & 53 & 44 \\
\hline & $B \times A$ & No & {$[-\mathrm{IL} 7$} & - & - & - & - & 35 & 60 \\
\hline \multirow[t]{2}{*}{9540} & $\mathrm{~A} \times \mathrm{B}$ & Yes & Standard & + & + & - & - & 15 & 80 \\
\hline & $B \times A$ & Yes & Standard & + & + & - & - & 7 & 89 \\
\hline \multirow[t]{2}{*}{$9384-2$} & $A \times B$ & Yes & Standard & - & - & + & + & 79 & 16 \\
\hline & $B \times A$ & Yes & Standard & - & - & + & ++ & 85 & 12 \\
\hline \multirow[t]{2}{*}{$9607-2$} & $A \times B$ & Yes & $\mathrm{E}-\mathrm{IL} .7$ & - & - & $+t$ & $+t$ & 7 & 91 \\
\hline & $B \times A$ & Yes & r-IL7 & + & ++ & $+t+$ & $+t$ & 10 & 87 \\
\hline \multirow[t]{2}{*}{9611} & $A \times B$ & Yes & [-IL7 & $+t$ & $+t+$ & $\mathrm{NT}^{b}$ & NT & 5 & 93 \\
\hline & $B \times A$ & Yes & {$\left[-I_{12} 7\right.$} & ++ & $+t+$ & $\mathrm{NT}$ & N'T & 8 & 90 \\
\hline 9610 & $A \times B$ & Yes & [-IL7 & + & + & - & - & 16 & 79 \\
\hline
\end{tabular}

T-cell lines were generaced from cell cultures which were induced with DCs as stimulator cell These T-cell lines were expanded according to different culture protocols (see Matertals and Methods)

- Designarion for HLA genotypically identical sibling pars T-cell lines were genetated in two different directions (a) by stimulation of $T$ cells of individual $A$ with DCs of individual B (designated as $A \times B$ ) and (b) within the same pair by stimulation of $T$ cells of individual $B$ with DCs of individual $A$ (designated as $B \times A$ )

The responding T-cell population was depleted or not for $\mathrm{CD}^{+}$cells before the initiation of the response with DCs

Two different ptotocols were used to generate T-cell. lines. either the standard protocol or the rIL-7 protocol (see Materals and Metbods)

T-cell lines were tested for cytotoxucity in a CML assay Responder cells (auto, autologous cells) and specific stımulator cells (spec) were used as target cells Cytotoxicity ar an effector-target ratio of 301 was expressed as $\%$ specific lysis,$-<10 \%$ lysis,,$+ 10 \%-20 \%$ lysis,,$++ 20 \%-50 \%$ lysis, and +++ , $>50 \%$ lysis

- T-cell lines were functionally tested in a standard PLT Proliferative responses were expressed in stimulation indices $-,<4,+, 4-10 ;++, 10-50$, and,$+++>50$

${ }^{\prime} \mathrm{T}$-cell lines were analyzed on a FACScan for the CD8 and CD4 phenotype

${ }^{8}$ As no growth (NG) was observed, no further analysis was performed

"NT, not tested

stimulator cells ( $\left.F_{1} g .3\right)$, Even at the highest concentration of stimulator cells, none of these APCs were capable of inducing a response between HLA genotypically identical sibling pairs, whereas the DCs were able to induce a detectable response at a concentration of 150-500 cells/ well. A reproducible variability in the strength of the primary $\mathrm{T}$-cell response was observed, both within and between the HLA-identical combinations (Fig. 4). Discrepancies in responsiveness may be caused by differences in antigenic incompatibilities, either in the absolute number or in differential immunogenicity between the HLA-identical individuals [20]. A known property of DCs to provide a proliferative stimulus to aurologous $T$ cells [3] was observed in three of the five positive
MLDCRs depicted in Fig. 4. The mechanisms underlying this DC characteristic are still not known.

Based on the absence of MLDCRs in the twin pairs (pair no. 9405 in Fig. 4) and the discrepancy between allogeneic and autologous MLDCRs in most of the combinations, we attempted to isolate $\mathrm{mH}$ antigen-specific $T$ cells. Therefore, the MLDCR-positive cultures were subsequently expanded using two different stimulation protocols, which resulted in $19 \mathrm{~T}$-cell lines. It is clear from Table 1 that $T$-cell lines could be generated between HLA genotypically identical siblings both from nondepleted purified $\mathrm{T}$ cells and from $\mathrm{CD}{ }^{+}$enriched $T$-cell populations. However, none of these DC-induced $T$-cell lines discriminated between the autologous and 
the specific stimulator cells (Table 1). Therefore, no assessment can be made of specific reactivity. We were also unable to detect $\mathrm{mH}$ antigen reactivity at the clonal level.

Despite the fact that we were unable to demonstrate putative $\mathrm{mH}$ antigen-specific reactivities, we show here two new properties of DCs. First, their capacity to induce in vitro primary T-cell responses between HLA genotypically identical MLR-negative sibling pairs and, second, their capacity of inducing autoreactive $T$ cells between HLA genotypically identical siblings.

\section{ACKNOWLEDGMENT}

The authors thank 1 . Bekker for coordinating the blood donations and Dr. F. Claas and Dr. A. Termijtelen for critically reading the manuscripr. This work was supported by grants from the Dutch Cancer Foundation (Koningin Wilhelmina Fonds) and the J. A. Cohen Institute for Radiopathology and Radiation Protection.

\section{REFERENCES}

1. Goulmy E: Minor histocompatibility antigens and their role in transplantation. In Morris PJ, Tilney NL. (eds): Transplantation Reviews, vol 2. Philadelphia, Saunders, 1988, p 29.

2. van Voorhis WC, Hair LS, Steinman RM, Kaplan G: Enrichment and characterization from peripheral blood. J Exp Med 155:1172, 1982.

3. Kuntz Crow M, Kunkel HG: Human dendritic cells: major stimulators of the autologous and allogeneic mixed leucocyte reactions. Clin Exp Immunol 49:338, 1982.

4. Steinman RM: The dendritic cell system and its role in immunogenicity. Annu Rev Immunol 9:271, 1991.

5. Nussenzweig MC, Steinman RM, Witmer MD, Gutchinov B: A monoclonal antibody specific for mouse dendritic cells. Proc Natl Acad Sci USA 79:161, 1982.

6. Nussenzweig MC, Steinman RM, Unkeless JC, Witmer MD, Gutchinov B, Cohn ZA: Studies of the cell surface of mouse dendritic cells and other leukocytes. J Exp Med 154: 168,1981

7. Knight SC, Fryer P, Griffiths S, Harding B: Class II histocompatibility antigens on human dendritic cells. Immunology 61:21, 1987.

8. Brooks CF, Moore M: Differential MHC class II expression on human peripheral blood monocytes and dendritic cells. Immunology 63:303, 1988.

9. Freudenthal PS, Steinman RM: The distinct surface of human blood dendritic cells, as observed after an improved isolation method. Proc Natl Acad Sci USA 87: 7698,1990 .

10. Steinman RM, Witmer MD: Lymphoid dendritic cells are potent stimulators of the primary mixed leukocyte reaction in mice. Proc Natl Acad Sci USA 75:5132, 1978.

11. Kast WM, Boog CJP, Roep BO, Voordouw AC, Melief CJM: Failure or success in the restoration of virus-specific cytotoxic $\mathrm{T}$ lymphocyte response defects by dendritic cells. J Immunol 140:3186, 1988.

12. Inaba K, Metlay JP, Crowley MT, Steinman RM: Dendritic cells pulsed with protein antigens in vitro can prime antigen-specific, MHC-restricted T cells in situ. J Exp Med 172:631, 1990.

13. Macatonia SE, Taylor PM, Knight SC, Askonas BA: Primary stimulation by dendritic cells induces antiviral proliferative and cytotoxic $T$ cell responses in vitro. J Exp Med 169:1255, 1989.

14. Melief CMJ: Dendritic cells as specialized antigen presenting cells. Res Immunol 140:902, 1989.

15. Goulmy E: HLA-A, -B restriction of cytotoxic T cells. In Ferrone S, Solheim BG (eds): HLA Typing: Methodology and Clinical Aspects, vol 2. Boca Raton, FL, CRC, 1982, p 105.

16. van Els CACM, Bakker A, Zwinderman AH, Zwaan FE, Van Rood JJ, Goulmy E: Effector mechanisms in graftversus-hose disease in response to minor histocompatibility antigens. II. Evidence for a possible involvement of proliferative T cells. Transplantation 50:67, 1990.

17. Tekolf WA, Shaw S: Primary in vitro generation of cytotoxic cells specific for human minor histocompatibility antigens between HLA-identical siblings. J Immunol 132:1756, 1984.

18. Schwarer AP, Zheng Jiang $Y$, Brookes PA, Barrett AJ, Batchelor JR, Goldman JM, Lechler RI: Frequency of anti-recipient alloreactive helper $\mathrm{T}$-cell precursors in donot blood and graft-versus-host disease after HLAidentical sibling bone-marrow transplantation. Lancet 341:203, 1993.

19. Theobald M, Nierle T, Bunjes D, Arnold R, Heimpel H: Host-specific interleukin-2-secreting donor T-cell precursors as predictors of acute graft-versus-host disease in bone marrow transplantation between HLA-identical siblings. N Engl J Med 327:1614, 1992.

20. van Els CACM, D'Amaro J, Pool J, Blokland E, Bakker $A$, van den Elsen PJ, van Rood JJ, Goulmy E: Immunogenetics of human minor histocompatibility antigens: their polymorphism and immunodominance. Immunogenetics 35:161, 1992. 